BIOKEMISTRI 18(1):9-13 (June 2006)

Available online at http://www.bioline.org.br/bk and at http://www.ajol.info/journals/biokem

Printed in Nigeria

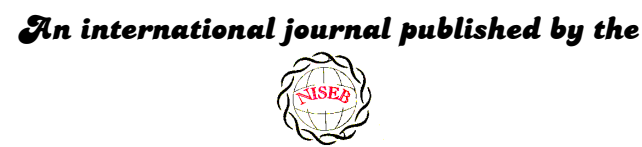

OVigerian Society for Experimental \&iology

\title{
Effect of thermo-oxidized soybean oil on growth rate and skeletal muscle enzyme activities in rats
}

\author{
Adewale Agboola ODUTUGA ${ }^{1}$ and Olu Isreal OYEWOLE ${ }^{2 *}$
}

1. Department of Biochemistry, College of Medicine, Igbinedion University, Okada, Nigeria.

2. Department of Chemistry and Biochemistry, Bowen University, Iwo, Nigeria.

Received July 15, 2004

MS/No BKM/2004/019, @ 2006 Nigerian Society for Experimental Biology. All rights reserved.

\begin{abstract}
Fresh and thermooxidized soybean oil diets were fed to rats for six weeks at two supplementation levels (5\% and 15\%). Rats fed with thermooxidized oil showed growth depression probably as a result of gross accumulation of decomposition products in the gut of the rats thereby reducing intestinal absorption. Alkaline Phosphatase (ALP) and Acid Phosphatase (ACP) were assayed in the skeletal muscle of the rats. Significant decrease in activity of the enzymes was recorded starting from the second week till the end of the feeding period in the rats fed with $15 \%$ thermooxidized oil diet. The decrease in activity of the enzymes might be due to cellular damage caused by peroxides and other products of heated fat which might have inhibited the synthesis of the enzymes or allowed them to leak out of the cell. Analysis of protein content in the skeletal muscle of rats after the feeding experiment shows no significant changes. This study suggests that prolonged consumption of thermally heated Soybean oil at high level could be toxic to the living system.
\end{abstract}

Keywords: Theromooxidized soybean oil, growth rate and skeletal muscle.

*Author to whom correspondence should be addressed. E-mail: iooyewoleoct72000@yahoo.com, Tel: 08033727617 


\section{INTRODUCTION}

When oils are heated, they generate free radicals. These highly reactive radicals lead to the production of primary products, which can undergo degradation reactions to form complex variety of products like hydroperoxides, aldehyde and 4-hydroxyalkenals which can escape from the membrane and cause disturbances at other sites ${ }^{1}$.

They also enter into reactions, with inorganic and organic chemicals (proteins, lipids and carbohydrates) particularly with key molecules in membrane and nucleic acids thereby producing a range of enzymatically damaging consequences $^{2}$. Extensive lipid peroxidation can result in membrane disorganization by peroxidizing mainly the poly-unsaturated fatty acids, which lead to changes in their composition. Such changes can lead to decrease in membrane fluidity and alteration in structure, which may be sufficient to cause cell death ${ }^{3}$.

From the nutritional standpoint, hydroperoxides destroy carotene, Vitamin A and tocopherols. They also denature protein by reacting with muscle proteins causing protein polymerization, which lead to decreased extractability and increased toughness. Epidemiological evidence has also suggested a relationship between the use of fried food and cancer incidence ${ }^{3}$.

The objective of this research was to investigate the effect of thermally heated Soybean oil on growth and its toxic effect on the living tissue.

\section{MATERIALS AND METHODS}

\section{Diet formulation}

Table 1 shows the feed composition. The components of each diet were mixed together and made into pellets after which it was oven dried.

\section{Management of rats}

Eighty albino rats divided into 4 groups were used for the experiment. Fresh and soybean oil heated for 10 days at 2 hours per day was used as component of rat diet. The composition of the soybean oil was at two levels (5\% and 15\%). The diet and water were given to the animals $a d$ libitum for a period of six weeks. Average weight of animals in each group was taken on weekly basis. Five rats were removed from each group at weekly interval and sacrificed. Their skeletal muscle were removed and analyzed for protein and enzyme activities.

Table 1: Diet composition (g/100g)

\begin{tabular}{|l|c|c|c|c|}
\hline Component & $\mathrm{A}$ & $\mathrm{B}$ & $\mathrm{C}$ & $\mathrm{D}$ \\
\hline Casein & 25.0 & 25.0 & 25.0 & 25.0 \\
\hline D-L Methionine & 0.4 & 0.4 & 0.4 & 0.4 \\
\hline D-L Lysine & 0.4 & 0.4 & 0.4 & 0.4 \\
\hline Corn starch & 41.2 & 41.2 & 25.0 & 25.0 \\
\hline Cellulose & 13.0 & 13.0 & 25.5 & 25.5 \\
\hline Sucrose & 10.0 & 10.0 & 3.7 & 3.7 \\
\hline Vitamin Mix & 1.0 & 1.0 & 1.0 & 1.0 \\
\hline Mineral mix & 4.0 & 4.0 & 4.0 & 4.0 \\
\hline $\begin{array}{l}\text { Soybean oil } \\
\text { fresh) }\end{array}$ & 5.0 & - & 15.0 & - \\
\hline $\begin{array}{l}\text { Soybean oil } \\
\text { (heated) }\end{array}$ & - & 5.0 & - & 15.0 \\
\hline
\end{tabular}

\section{Preparation of tissue homogenate}

Rats were anaesthetized by putting them in jar containing cotton wool soaked in chloroform. They were then dissected and the skeletal muscle in the femur, tibia and fibula removed into ice cold $0.25 \mathrm{M}$ sucrose buffer to maintain the organ Integrity. The organ was washed of blood, weighed and then homogenized in ice cold $0.25 \mathrm{M}$ sucrose buffer ( $\mathrm{x} 6$ dilution) using mortar and pestle. The homogenate was then frozen to be analyzed for protein and enzymes.

\section{Protein concentration determination}

The skeletal muscle was homogenized with $0.25 \mathrm{M}$ sucrose buffer to make 30 times dilution. The protein concentration in the tissue was then determined using Biuret method ${ }^{4}$. This method is based on the principle that when Copper II ion is added to protein in alkaline medium, a purple colour chelate is formed between the Copper II ion and peptide bonds. The intensity of the purple colour is a measure of the amount of protein present.

\section{Enzyme activity determination}

Alkaline phosphatase (ALP) and Acid phosphatase (ACP) activities in the skeletal 
muscle of the rats were determined using the method described by Fishback ${ }^{5}$. The method is based on the principle that the enzymes hydrolyse Paranitrophenyl phosphate (PNPP) to Paranitrophenol (PNP) and phosphoric acid at alkaline and acidic medium respectively. The PNP confers yellowish colour on the reaction mixture and its intensity is then measured using the spectrophotometer.

\section{RESULTS AND DISCUSSION}

\section{Growth rate of the rats}

Figure 1 shows the growth pattern of the 4 groups of experimental animals. Rats fed with thermooxidized soybean oil (group B and D) shows growth depression while those fed with fresh oil (group A and C) have unhindered growth throughout the experimental period. Molecular changes that took place during lipid oxidation modified the physical properties and utility of lipids. These modifications affect digestibility, intestinal absorption and energy values of the diet and may result in depression of weight and growth ${ }^{6,7}$. The bad taste and odour that characterized oxidized oil can also lead to reduce feed intake and palatability in the experimental rats thereby leading to growth retardation $^{8}$.

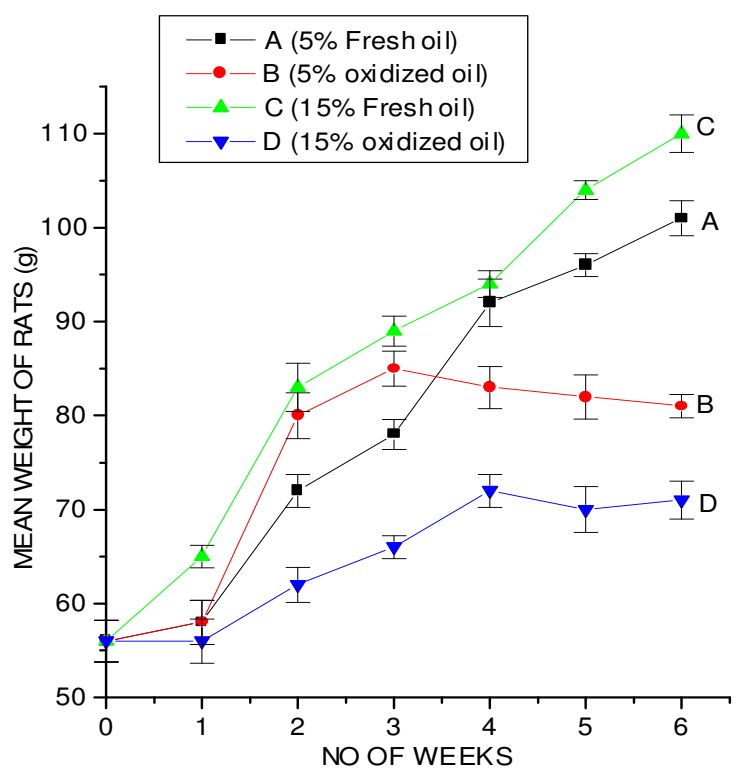

Figure 1: GROWTH PATTERN OF EXPERIMENTAL RATS Each spot is the mean weight of all rats in each group

\section{Protein content of the tissue}

Figure 2 shows the protein concentration $(\mathrm{g} / 100 \mathrm{~g}$ tissue) of the skeletal muscle of rats in each group at the end of the feeding period. Statistical analysis shows that there is no significant difference in the protein concentration of the skeletal muscle of rats fed with fresh oil and those with thermooxidized oil at the two supplementation levels (5\%and 15\%). This appears to indicate that the muscle proteins of the animal are not adversely affected by ingestion of the heated oil. Significant loss in protein content was not observed probably because the extent of thermooxidation of the soybean oil was not sufficient to cause adverse effects on muscle protein.

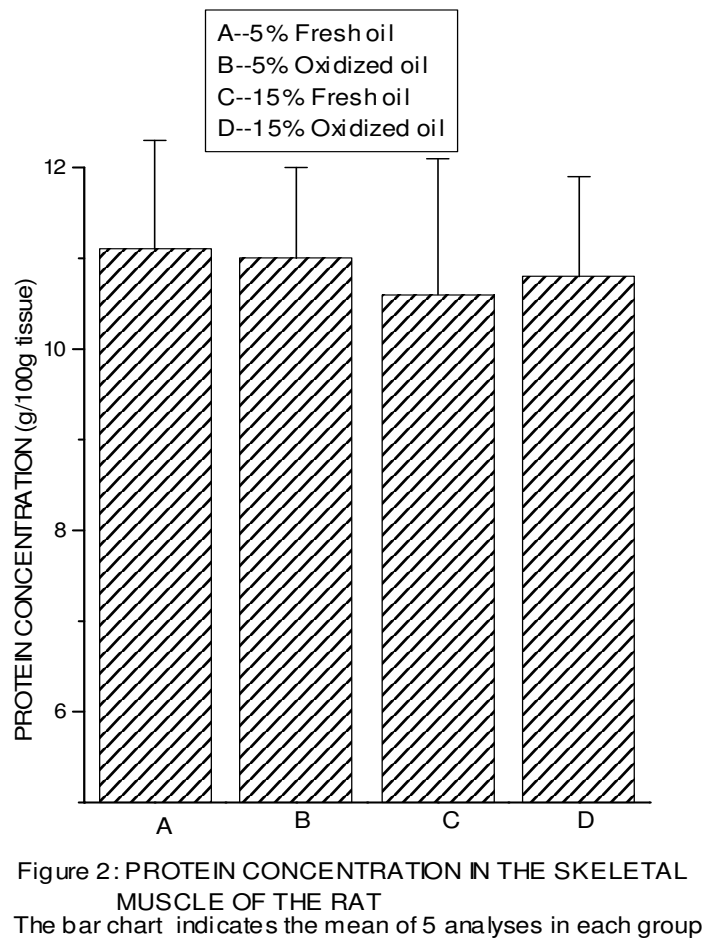

\section{Enzyme activities}

Figures 3 and 4 show the specific activities of alkaline phosphatase and acid phosphatase respectively. Significant decrease in ALP and ACP activity was recorded in the skeletal muscle of the rat fed with $15 \%$ thermooxidized oil diet (group D) starting from the second week but the reduced activity was not significant until the $4^{\text {th }}$ week with group B (5\% thermooxidized oil). 


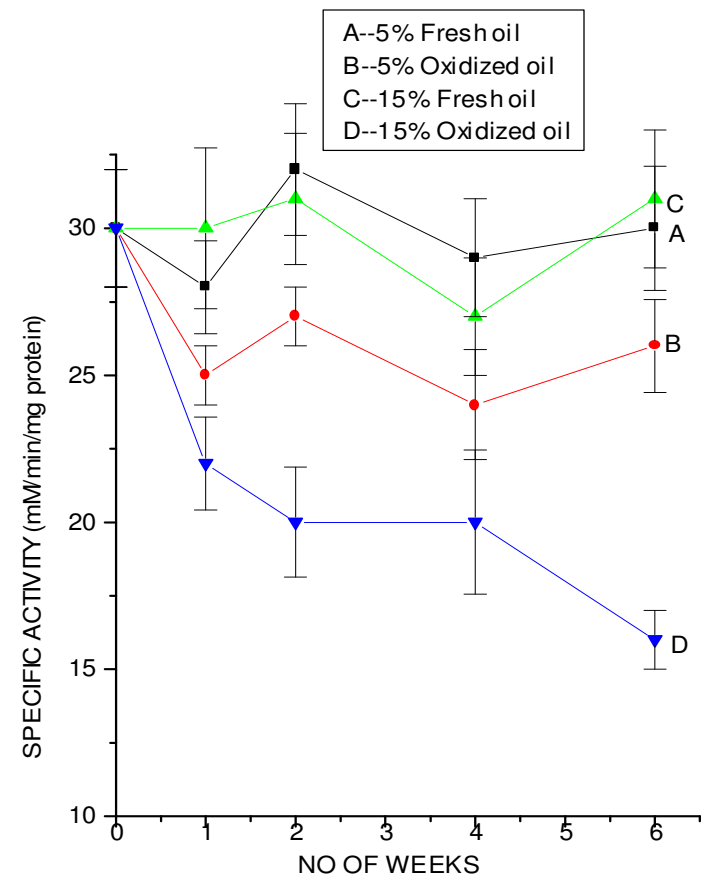

Figure 3: ALKALINE PHOSPHATASE SPECIFIC ACTIVITY IN THE SKELETAL MUSCLE OF THE RAT

Each spot is the mean of 5 analyses in each group

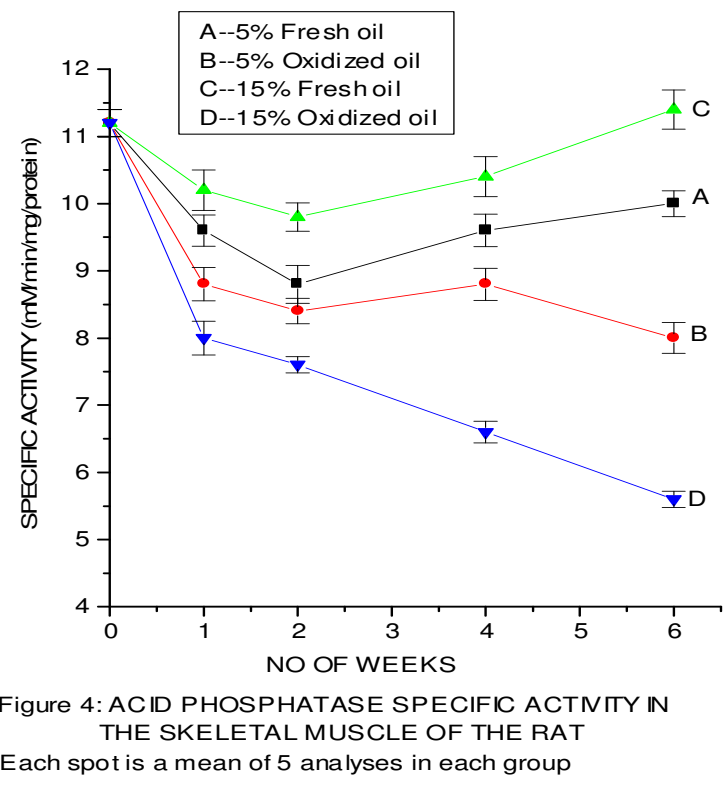

ALP is a membrane bound enzyme; the reason for its low activity in the affected rat might be due to inactivation of the enzyme by the free radicals generated from the oxidized oil ${ }^{2}$. It was also reported that oxidizing agents such as peroxides and hydroperoxides are inhibitors of ALP'.
Since ACP is associated with the lysosomes, membrane damage by free radicals could lead to escape of the enzymes from the lysosomes out of the cell. Significant decrease in enzymes activity was not noticeable in tissue of rats fed with $5 \%$ oxidized oil until the $4^{\text {th }}$ week probably because the free radicals generated in the first 4 weeks were not adequate to bring about pronounced cellular damage ${ }^{10}$.

\section{CONCLUSION}

Consumption of thermally heated soybean oil could bring about biological effects ranging from poor growth to tissue toxicity at high levels. However, at low levels, toxicity could only result from prolonged consumption. It is hereby recommended that handling and processing techniques involving heat treatment that may bring about lipid deterioration should be discouraged in fatty foods.

\section{REFERENCES}

1.Chow C.K. (1989) Biological and toxicological properties of fatty acids and their derivatives. In Johnson R.W. ed. Fatty acids in industry N.Y. 617-658.

2.Cotran R., Kumar V. and Robin S. (1989) Robin's pathological basis of diseases. 4th ed. W .B. Sanders Co. Harcourt. Brace Johanorich Inc. 512-524.

3.Halliwell B. and Gutteridge J.M.C. (1989) Free radicals in biology and medicine. Clarendon press, Oxford, England pp 43-50.

4.Henry R.J., Cannol D.C. and Winkelman J.W. (1974) Clinical Chemistry: Principle and techniques. $2^{\text {nd }} \mathrm{Ed}$

5.Fishback F. (1996) A manual of laboratory and diagnostic tests. 5th ed. Philadelphia 378-379, 382-384.

6. Jacobson G.A. (1991) Quality control in deep fat frying operations. Food technol. 45:7274.

7.Miller R.W. and Long P.H. (1990) A 91 day feeding study in rats with heated olestra / vegetable oil blends. Food Chem. Toxic. 28: 307-315.

8.Sanders T.A.B. (1989) Nutritional aspect of rancidity. In Allen J.C and Hamilton R.J. ed. Rancidity in foods 7: 125-139. 
9.Kagan V. E. (1988) Lipid peroxidation in biological biomembranes. Bocaraton CRC press $52-59$.

10.Henning B. and Chow C. K. (1988) Lipid peroxidation and endothelial cell injury.
Implications in arteriosclerosis. Free radical biol. 4: 99-106. 